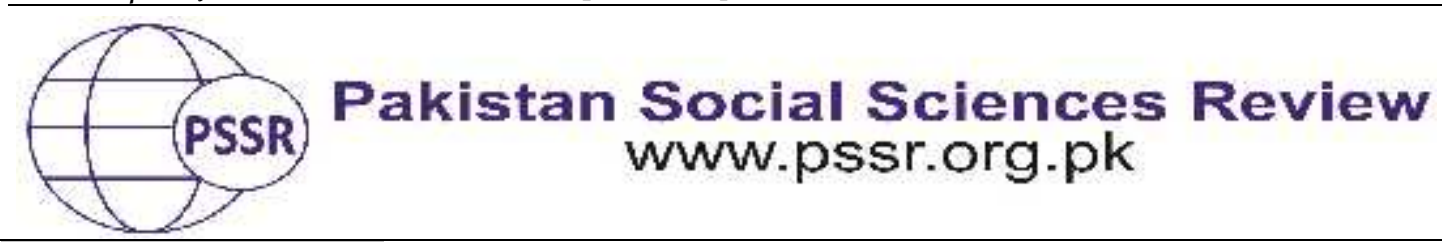

RESEARCH PAPER

\title{
Politeness Strategies in Imran Khan's Maiden Speech as Prime Minister of Pakistan
}

Dr. Ashiq Hussain*1 Muhammad Nadeem Anwar ${ }^{2}$ Muhammad Zahid Mian ${ }^{3}$

1. Associate Professor, Department of English, Higher Education Department, Lahore, Punjab, Pakistan

2. Assistant Professor, Department of English, Government Graduate College of Science, Lahore, Punjab, Pakistan

3. Assistant Professor, Department of English, Higher Education Department, Lahore, Punjab, Pakistan

\begin{tabular}{|c|c|}
\hline 18 & \\
\hline 21 & Pakistanis immediately a \\
\hline $\begin{array}{l}\text { ds: } \\
\text { hd Bald } \\
\text { aving } \\
- \\
\text { hg Acts, } \\
\text { politeness, } \\
\text { Positive }\end{array}$ & $\begin{array}{l}\text { transcribed text of the speech, were analyzed } \\
\text { Brown and Levinson's theory of politeness. } \\
\text { revealed that the addresser used different } \\
\text { strategies namely positive politeness str }\end{array}$ \\
\hline $\begin{array}{l}\text { *Corresponding } \\
\text { Author } \\
\text { dpicolleges.hed@g }\end{array}$ & $\begin{array}{l}\text { ies, and bald off } \\
\text { ss strategies have } \\
\text { liteness strategies } \\
\text { the listener(s). }\end{array}$ \\
\hline
\end{tabular}

\section{Introduction}

One of the greatest blessings endowed to human beings is language. Language is a unique ability through which humans can communicate with one another. According to Ward Haugh (1987) language permits people to say things to each other and express their communicative needs. It suggests that people express their emotions, passions, and feelings through language. They can exchange information and ideas through it. Besides, language can also be used to maintain any kind of relationship whether it is social, political, personal, interpersonal, or intrapersonal. 
The phenomenon of communication is not as simple as it looks. In order to communicate one should try to communicate efficiently and accurately. It means that interlocutors, during interaction, should be on cooperative terms with each other. Brown and Yule (1986) lend support to the idea in these words. They are of the opinion that people cooperate on simple mechanics of speech. The speaker tries to utter such words as can be perceived conveniently by the listener. He attempts to finish his talk within the required limit of words. The listener, on the other hand, strives to understand well what is being expressed. In other others, interlocutors try to make interaction successful by following a general rule or principle i.e. politeness. According to Renkema (1993) politeness is a strategy which helps run a conversation smoothly.

Politeness, as a strategy, is necessary in conversation. It is so because it not only helps establish social relation between interlocutors but also makes interaction appropriate and comprehensible. Ward Haugh (2006) while explaining the concept of politeness states that it is the most important aspect in language in considering the feelings of others to whom one is interacting. Robin Lakoff, as quoted by Fukushima (2003) also lends support to the idea that politeness must be prioritized in an interaction in order to sidestep misdemeanor than to attainclearness. Here it can be established politeness has obligatory role in an interaction that everyone should be polite to make social interface goes well. It is related to cognizance and concern of the interlocutor's face.

Brown and Levinson (1978) were the researchers who first proposed the idea of politeness which means everyone should cogitate face as elementary requirements so that one might be familiar with each other's desire. There are two kinds of face i.e. positive face and negative face. Positive face is a kind of face which needs to be appreciated and approved as the members of the same group. Negative face, conversely, is a kind of face which desires to be free from intervention and imposition.

In communication or speech, writes Brown and Levinson (1996), certain acts or words can intimidate the face when those acts or words go contrary to the face requirements of either the addressee or the addresser. The face can also be threatened when those actions or words go contrary to the face wants of the addressee. In order to decrease the effect of such acts the speaker may use politeness strategies, positive as well as negative, to satisfy the hearer's wants. Such strategies lessen the FTA based on the considerations of power (p), distance (D), and rating to imposition (R). Consequently, if the addresser makes FTA without an effort to maintain the addressee's face, it will cause roughness in communication.

Political speeches, debates and interviews are considered rich enough to be analyzed in various ways. Political speeches, in particular, entail rich language which may report up-to-the-minute insight to the field language and linguistics. In fact researchers have been analyzing political speeches at morphological, syntactic, semantic, discourse, critical discourse and pragmatic levels. The speeches of eminent 
world leaders have been pragmatically analyzed (e.g. Handoko 2014; Kasuma, 2014; Sari, 2016; Alavidze, 2018; Yasmeen et. al. 2014; and Khan and Anwar, 2016 etc.). A number of researches have been conducted on Imran Khan's political speeches but most of them are based on CDA (for instance Khalil et al. 2017; Sibtain et al. 2020 etc.). There is dearth of research regarding pragmatic analysis of his famous speeches. In order to fill the gap the current study uses Imran Khan's maiden speech as Prime Minister of Pakistan for the purpose of pragmatic analysis.

The present study is significant as it provides insights to the pragmatic phenomenon of politeness used by political leaders in general and a renowned Pakistani political figure Imran Khan in particular. Politeness strategies serve to mitigate face threatening acts. The study is also important as it enlightens students, teachers, scholars, researchers, and linguists. It will clarify and analyzing politeness (politeness strategies) in famous political speeches.

\section{Literature Review}

Politeness, a very important concept of Pragmatics and a base of social interaction, has been defined by several linguists in their own words. Watt (2003) defines politeness as an ability to please someone through an action. Foley (1997) terms politeness as a battery of social skills which aims at ensuring that everyone feels affirmed in an interaction. Lakoff (1979) calls it a tool which is used for decreasing conflict or friction in communication. Holmes (1992) says that politeness entails considering of others' feelings in order to make him feel better.

The concept of politeness was touched upon by different linguists in their theories. First one is Cooperative Principles given by Grice (1975). Second are Leech's (1983) politeness maxims. Third in this regard is the politeness theory propounded by Brown and Levinson (1987). The theory mentioned in the last i.e. Brown and Levinson's (1987) politeness theory is relevant to the current study.

Brown and Levinson (1987) while defining face write that face is something that is emotionally invested and that can be preserved or improved. It is such an important phenomenon that it should be continuously heeded during interaction. Goffman (1969:3) visions the conception of face as the positive social worth a person effectually asserts for himself by the line others take up he has taken during specific interaction. In any communicative situation the partakers 'goal line is the safeguarding of face. In daily dialogue, we try to evade elusive and private issues, we bolster our conversers, and we elude even variance. We also attempt to make our word clear by emphasizing significant objects or important information. We repeatedly use non-verbal response if we do not comprehend others. In short, we are considering face of ourselves and our talkers. In this way politeness is an activity which serves to increase, uphold or safeguard face.

Brown and Levinson (1987) further hold that face is of two types: positive face i.e. ones wish be appreciated, approved of and esteemed by others and negative face i.e. ones desire to preserve his domain and shun being imposed on by others. In 
day to day conversation others may cause threats to an individual's self-image which may be termed as "face threatening act". These acts may pose threat to the freedom of interlocutors in terms of positive face or negative face. For the purpose of avoiding FTAs during conversation, according to Brown and Levinson (1987) there are different strategies which are given below:

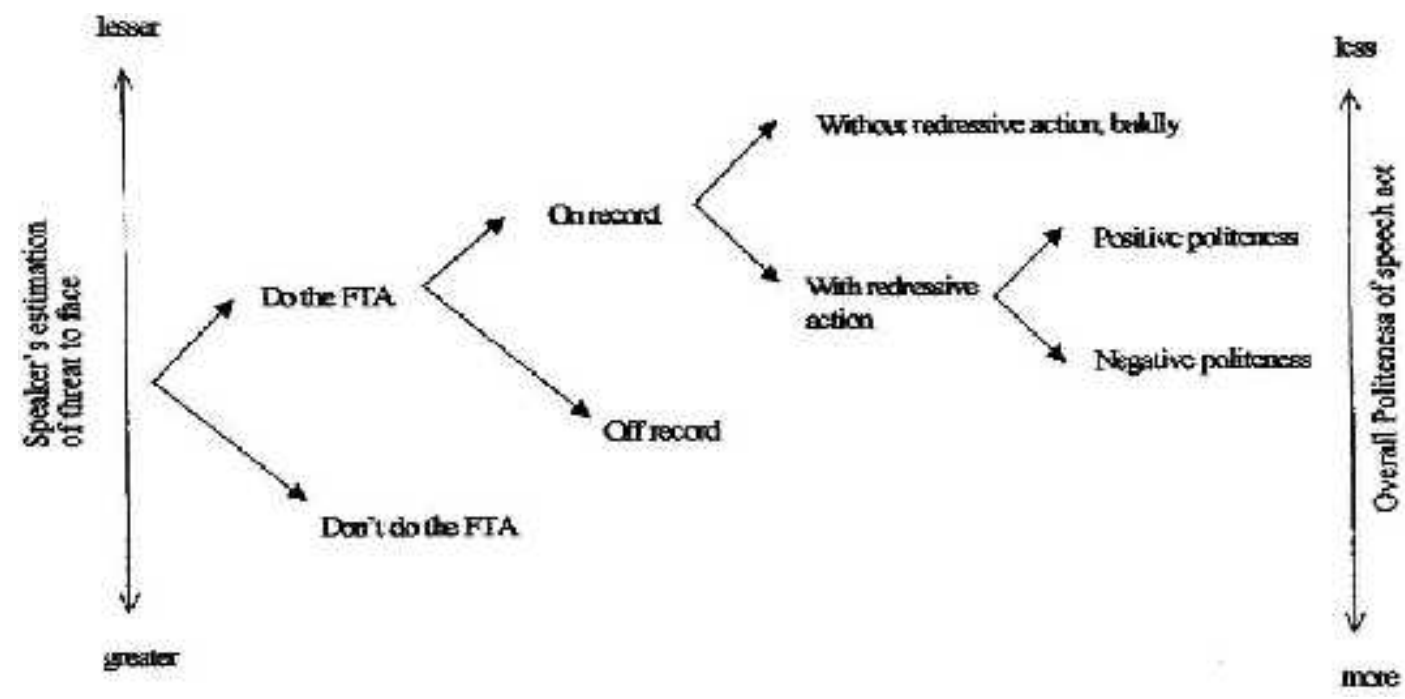

Figure 1 Selection of strategies following anFTA

FTA encounter

Don't do the FTA Do the FTA

Off record On record

with redressive action

Negative politeness

Positive Politeness

without redressive action

In fact, in a contact members may face a situation where a speech act may pose a threat. In that situation, the utterer has diverse choices to adopt and different steps to take. He has to make rapid decisions. The initial judgment to be made is whether to do the FTA or not. If the contributors choose for the first choice which is to do the FTA then they will have a second decision, which is going off record or on record. In the first case, participants may show their intents through clues or indirect propositions whereas in the second one their intentions are obviously and unswervingly articulated. 
At this stage, the interlocutors' option is to go on record; they will have two more decisions to do while performing their FTA, using the redressive action or without using the redressive action. Redressive actions merely mean the struggle made by the participants to moderate the force of the speech act. So, participants can make the FTA without redressive actions using direct strategies or can use the redressive action strategies. Additionally, speaker as well as hearer may make use of both positive politeness strategies and negative politeness strategies for saving faces of addressee as well as addressor. Both types of strategies are:

Table 1

Politeness strategies

Positive Politeness strategies Negative Politeness Strategies

\begin{tabular}{|c|c|c|c|}
\hline Notice, attend to hearer & Joke & $\begin{array}{l}\text { Be conventionally } \\
\text { indirect }\end{array}$ & $\begin{array}{l}\text { State FTA as } \\
\text { general rule }\end{array}$ \\
\hline $\begin{array}{c}\text { Exaggerate (interest, } \\
\text { approval, and sympathy } \\
\text { with hearer) }\end{array}$ & $\begin{array}{c}\text { Assert of } \\
\text { presuppose } \\
\text { speaker's } \\
\text { knowledge of } \\
\text { and the concern } \\
\text { for hearer's } \\
\text { wants }\end{array}$ & $\begin{array}{l}\text { Using question, } \\
\text { hedging }\end{array}$ & Nominalize \\
\hline $\begin{array}{c}\text { Intensify interest to } \\
\text { hearer }\end{array}$ & Offer or promise & Be optimistic & $\begin{array}{c}\text { Go on record as } \\
\text { incurring debt or } \\
\text { not as indebting } \\
\text { the hearer }\end{array}$ \\
\hline $\begin{array}{c}\text { Use in-group identity } \\
\text { markers }\end{array}$ & Be optimistic & $\begin{array}{l}\text { Minimize the } \\
\text { imposition } \mathrm{Rx}\end{array}$ & \\
\hline Seek agreement & $\begin{array}{c}\text { Include both } \\
\text { speaker and } \\
\text { hearer in the } \\
\text { activity }\end{array}$ & Give deference & \\
\hline Avoid disagreement & $\begin{array}{l}\text { Give or ask } \\
\text { reason }\end{array}$ & Apologize & \\
\hline $\begin{array}{l}\text { Presuppose/raise/assert } \\
\text { common ground }\end{array}$ & $\begin{array}{l}\text { Assume or assert } \\
\text { reciprocity and } \\
\text { give gifts }\end{array}$ & $\begin{array}{l}\text { Inter personalize } \\
\text { speaker and hearer }\end{array}$ & \\
\hline
\end{tabular}

In the second sort of strategies participants aim for reducing the FTA and this would embrace the use of indirect formulae or direct means of prevarication and extenuation. Finally, in order to exemplify the above notions and relations, let us use an instance of speech act which is refusal.

i. On record without redressive action: means direct refusal, for example: "Irefuse" 
ii. On record (without redressive action): means to refuse explicitly with or without politeness strategies.

iii. Off record: means not to refuse explicitly but give a listener a hint so that he or she can infer that the speaker means refusal.

iv. Do not do the FTA: means giving up refusing.

The current section reviews related past researches in order to find out research gap for the current study.

Handoko (2014) conducted pragmatic analysis of a political speech delivered by Prime Minister of Australia. The speech delivered by Tony Abbot was very important as it was related to bilateral relations with Indonesia on tapping issue between both the countries. The speech was analyzed in terms of application of FTA and politeness strategies. The methodology applied was qualitative. The text of the speech was bifurcated into words and sentences which was used as data. The analysis of the data was done through document analysis approach. Through document analysis politeness strategies used by the speaker were determined. The data indicated that the positive faces of both the speaker and that of the hearer were threatened. In the meantime for the negative face, only the negative face of the hearer was endangered. Tonny Abbot used four types of strategies like bald on record, positive politeness strategies, negative politeness strategies and off record. However, he used positive politeness strategies frequently because he wanted the hearer to agree and corroborate his opinion. He also threatened negative face using positive politeness strategies.

Kasuma (2014) investigated politeness strategies in Barrack Obama's speech which he delivered in Democratic National Convention. The speech was significant with regards to politeness strategies as it was delivered by a presidential candidate to the audience and the officials of Democratic Party. The use of politeness strategies deems necessary in such speeches. The data were the speech. The data were analyzed inductively through the observation done the researcher himself. The data collected were analyzed using descriptive qualitative approach. The results of the study indicate that the speaker used all types of politeness strategies. Bald on record was used whenever speaker wanted to do FTA with maximum efficiency more than he want to satisfy hearer's face. The speaker also used positive politeness strategies, negative politeness strategies and off record strategies but for serving different purposes.

Sari (2016) in a PhD dissertation analyzed Obama's victory speech in terms of application of politeness strategies. The research, focusing on Barrack Obama's utterances in his victory speech in Chicago, November $4^{\text {th }}, 2008$, conducted with descriptive qualitative methodology. The results of the study reveal that the American president applied politeness strategies. He applied positive politeness strategies to show face threatening acts (FTA). He applied positive politeness 
strategies by joking, intensifying interest, exaggerating, complimenting, including $\mathrm{S}$ and $\mathrm{H}$ in the activity, by being optimistic, offering, and assuming or asserting reciprocity.

Alavidze (2018) argues that politicians, in their political speeches, are concerned with their public image so these speeches require pragmatic analyses in terms of politeness. The researcher, in order to identify linguistic and social behavior, of Donald Trump analyzed his presidential addresses. The study uses Brown and Levinson's (1987) framework for the purpose of analyzing addresses as regards politeness. The study claims that American President, Donald Trump, employs negative as well as positive politeness strategies. He employs these strategies to show that he has strong interest in his public, to show that he is on familiar terms with his people and to claim that he is a member of a common social group.

Yasmeen et. al. (2014) examined the politeness strategies employed by Pakistani politicians in their speeches during a session of Privileged Motives. The study was based on the hypothesis that Pakistani politicians remain impolite during session despite the rules of business of the assembly bound them to be polite during sessions. Additionally they do not bother the hearers' face, their self-images. The data were collected in the form of documented debates of the Punjab Assembly from 2008 to 2013. The data were analyzed qualitatively. The study claimed that Pakistani politicians employed numerous strategies like balk on record, positive politeness, negative politeness and off record. Most frequently used strategy among these was on record strategy to show power the carefree style of communication. The data showed that the politicians did not use imperatives. They used less formal and mixed language to express their feelings and ideas paying little attention to the formality.

Khan and Anwar (2016) pragmatically analyzed the transcribed words of interview given by Donald Trump to The New York Times. The objective of the investigation was to ascertain what type of positive and negative politeness strategies were used by the speaker during the interview. It also attempted to determine the elements inducing interlocutors in selecting any one of the two types of strategies i.e.positiveand negative politeness strategies. The study was based on qualitative analysis of the data which, taken in the form of transcription from internet sources, were analyzed descriptively. The results of the study suggest that opinion columnists, reporters, and editors employ more negative politeness strategies than the guest because of social distance between them and the newly elected President. However, social distance, relative power and rate of imposition aid the selections made by interlocutors.

Khalil et. al. (2017) investigated Imran Khan' speech delivered at Shaukat Khanum hospital two days prior to general election (2013). The researchers, in order to uncover hidden ideologies, analyzed the speech through critical discourse analysis approach. As far as the methodology of the study was concerned it was qualitative in nature. Norman Fairclough's (1995) model was used as theoretical 
framework. The analyzed data suggested that political leader, in their discourses, consciously project certain ideologies implicitly. Imran Khan, then chairman of Tahreek e Insaaf, employed linguistic strategies in his speech for furthering his agenda. Such speeches need to be investigated to make them simple for laymen.

Sibtain et. al. (2020) have lately analyzed the victory speech of Imran Khan delivered at Prime Minister House. The aim of the study was to explore rhetorical and persuasive strategies used by newly elected Prime of Minister Pakistan in his speech. The study employed qualitative research approach. It used Aristotle's Rhetoric model as theoretical framework. Themodelincluded ethos, pathos, logos and other persuasive strategies like use of predication strategy, personal pronouns, and positive self-presentation and negative others-presentation. The results of the study indicated that Imran Khan knowingly used such persuasive strategies in his discourse as project his ideologies. Aristotelian rhetorical strategies like prediction strategies, rhetorical strategies etc. were used several times to convince the audience to follow his agenda.

The literature reviewed so far manifested that the political speeches of world famous political leaders have been pragmatically analyzed (e.g. Handoko 2014, Kasuma2014, Sari 2016, Alavidze 2018, Yasmeen et. al. 2014, Khan and Anwar 2016 etc.). The review concerned literature also suggested that a few speeches of Imran Khan have been analyzed but through CDA approaches (like Khalil et. al. 2017, Sibtain et. al. 2020 etc.). However, there is a need to pragmatically analyze Imran Khan's maiden speech which he addressed to the nationas22nd Prime Minister of Pakistan.

\section{Material and Methods}

There are two main research paradigms i.e. quantitative research design and qualitative research design. The first one deal with numeric data whiles the second one analysis non- numeric data. While highlighting the advantages of qualitative research paradigm, Strauss and Corbin (as cited in Anwar et. al. 2015) claim that this approach gives better options to perceive any unknown phenomenon. They further state that this approach is employed to gain in-depth insight into the things about which little is known. The present study aims at analyzing the linguistic politeness strategies in a speech delivered by Imran Khan to the nation. As the data are in words, qualitative research design is appropriate for the present study. For descriptive qualitative analysis of the data the transcribed manuscript of Imran Khan's first speech as PM of Pakistan was taken from http://www.thenews.com.pk/latest/357736-complete-test-of-imran-khans-maidenspeech. The speech was an address to the whole nation soon after he took oath as 22nd PM of Pakistan. The current speech was taken as data for the study because it was first formal address by Imran Khan to the nation and its text was rich enough to have several politeness strategies. For data analysis Brown and Levinson's politeness theory provided theoretical base. 


\section{Results and Discussion}

The current section answers the research questions of the study. It analyzes different types and functions of politeness strategies employed by Imran Khan in his maiden speech as Prime Minister of Pakistan.

\section{Datum 1. First of...22 years ago. (sc.1)}

In the above sentence Imran Khan, newly elected Prime Minister, wants to express his feelings of gratitude for his workers who have struggled hard for the last 22 years. The speaker's words carry positive politeness strategy (notice, attend to $\mathrm{H}$ ) as they satisfy hearer's (workers) positive face because the speaker approves their wants i.e. they like to be appreciated after a long struggle.

\section{Datum 2. I am remembering ...here today. (scs. 4-7)}

In the utterance, under analysis, the speaker expresses his deepest sympathy for Ahsan Rasheed and Saloni Bukhari who started with him in a mission. He also pays tribute to the other workers who, despite being teased by the opponents, have been very committed and steadfast throughout their political struggle. The speaker employs positive politeness strategy (sympathy with $\mathrm{H}$ ) as well as negative politeness strategy (be conventionally indirect). Be employingthesestrategies develops solidarity with his workers and remains inclusive because this is not only his success. This is success of the workers.

\section{Datum 3. First of all... these challenges. (scs.8 \& 9)}

The speaker attempts to take his hearers into confidence. He says that he will not hide anything from the nation. He also promises to put forward the solution of all the challenges. He employs positive politeness strategy (offer or promise) to redress the threat of FTA. The function of this strategy is that he promises to take the whole nation on board and whatever he does would aim at their betterment.

\section{Datum 4. Presently Pakistan ... the other. (scs. 12)}

The speaker, in these lines, provides facts and figures regarding foreign debt of Pakistan. He says that the previous governments of, PPP and PML (N), have increased the debt several times during the last 10 years. The speaker has done the FTA but by remaining off record. He does not directly name the political parties responsible for enhancing the foreign debt but hints them indirectly. Using off record strategy, Mr. Khan shows political maturity and does not malign his political opponents straightaway.

\section{Datum 5. Insha Allah, we ... before you.(scs.15)}

While addressing to the nation newly elected Prime minister says that he will bring all the facts in front of the nation. He promises to do it as the previous governments have been hiding several facts from the nation. He uses positive 
politeness strategy (offer or promise) to satisfy the hearers' positive face. This strategy reveals inclusiveness and that he will hide nothing from the people. Every fact will be in their knowledge which will ensure transparency.

\section{Datum 6. Where that... that money? (scs.15 \&16)}

The questions have been asked to the hearers. The hearers may include the nation as well as the previous rulers. In order to decrease the rate of imposition the speaker uses negative politeness strategy (using question). He makes the audience realize that their hard earned money was embezzled by the previous governments.

Datum 7. Today we... those loans. (scs. 17)

The speaker is telling his hearers that they have to borrow money to pay the interest on these loans taken by the previous governments. By using "we" he employs positive politeness strategy (include both speaker and hearer in the activity). By employing this strategy them considers himself and the nation a group which striving hard to get the country out of economic crisis.

Datum 8. In the... those loans. (scs. 18)

Here again the speaker argues that Pakistan's economy is facing pressure owing to foreign debts which the previous governments have been taking. In this utterance he has indicated the PPP government as the major party responsible for piling up debt. He has done this FTA through bald on strategy. The function of this strategy is that he has held responsible for today's economic woes.

\section{Datum 9. No need ... this situation. (scs.20)}

Although the speaker has been highlighting the issues faced by the people yet he is very hopeful. He wants his people to not to be despaired. He does so by employing positive politeness strategy (be optimistic). By using this strategy he remains optimist and consoles the nation not be hopeless.

Datum 10. We will... way, InshaAllah. (scs.31)

The speaker expresses his firm resolution that he, with the help of Pakistanis, will change the destiny of the nation. He uses two positive politeness strategies i.e. include $\mathrm{S}$ and $\mathrm{H}$ in the activity and be optimistic.

Datum 11. Pakistan's PM...1100 canals. (scs.35 \& 36)

Newly elected Prime Minister of Pakistan indicates the lavish life style of the previous Prime Ministers. He impresses upon the audience, by telling facts and figures, that Prime Minister house has been one of the sources of burden to the economy of the country. The speaker has used bald off strategy as he has not directly pointed any of previous prime ministers. 
Datum 12. Why do ... somecountry? (scs. 43-45)

The questions are being posed to the audience. The hearers may include the nation as well as the previous rulers. In order to decrease the rate of imposition the speaker uses negative politeness strategy (using question). He persuades the audience that their hard earned money has been embezzled and squandered away by the previous governments.

\section{Datum 13. If we... of school.(sc.49)}

Prime Minister of Pakistan expresses his concern over the issue of education. He says that 2.5 billion Pakistani children are out of school which is an alarming situation. By using the pronouns "us" and "we" he employs positive politeness strategy (include both speaker and hearer in the activity).

\section{Datum 14. I was ... such challenges.(scs.84 \& 85)}

In this instance the speaker is indirectly pointing out the criticism done on him whenever he wished to become a captain or bowler, to make a private sector university and to establish a third political party in Pakistani politics. He does not use the names of forces criticizing him. He indirectly points them out. So he uses bald off strategy in this utterance.

\section{Datum 15. You all ...be called. (scs. 86-96)}

Normally the newly elected Prime Ministers give several pledges to the nation. Imran khan in his maiden speech as Prime Minister of Pakistan is doing the same. The datum11 extracted from his speech is a testimony to it. He uses positive politeness strategy (offeror promise) to satisfy the face wants of the hearers. He again remains inclusive and hopes that the nation will be his team and he will be their captain to lead them to their destination.

\section{Datum 16. We have...our feet.(sc. 102)}

The speaker, in the above short sentence, persuades his hearers that they should be responsible enough to stand on their own feet. He uses positive politeness strategy (include both speaker and hearer in the activity). He remains inclusive and heartens them.

\section{Datum 17. I announce ...illegal means. (sc. 112)}

The speaker, in the utterance under discussion, informs his audience that he has ordered to form a powerful task force to bring that money back which has been transferred abroad through money laundering or illegal means. Here he is posing a threat to his opponents. But he decreases FTA by being indirect. He uses negative politeness strategy (be conventionally indirect). Using negative politeness strategy he condemns the previous political dispensation indirectly that they were corrupt and looted the money from the exchequer. 
Datum 18. I announce ...one-window operations. (sc. 116)

In the above sentence the speaker addresses to the audience in general and local and international businessmen in particular. He assures them that his government would facilitate the business enterprises and investment in the country. For achieving his purpose he used two positive politeness strategies (assert the concern for the hearer and offer or promise).

\section{Datum 19. I would ... helped out.(sc. 117)}

The speaker addresses to the families whose dear ones have been put in jails abroad owing to one reason or the other. He gives them good news that his government intends to do something for their dear ones who are in jails abroad. He used positive politeness strategy (give gift to hearer in the form of cooperation).

Datum 20. To cleanse ... and funding. (sc. 120)

Through the above mentioned utterance the speaker warns the audience in general and the corrupt individuals in particular that his government would facilitate National Accountability Bureau in the process of accountability. He actually used two negative politeness strategies. be conventionally indirect and impersonalize speaker and hearer.

\section{Datum 21. The government ... public money.(sc.120)}

The speaker pledges that his government would initiate whistleblowers act across the country as was introduced in KPK in the past. He applied negative politeness strategy for achieving his aim. The strategy applied was named as 'promise'. Through the application of this strategy the speaker attempted to reduce the threat to the hearer's positive face.

Datum 22. Following the ... the democracy. (sc. 123)

The speaker addresses to those who are involved in corrupt practices. He categorically states that crackdown would be done against those who are corrupt. In other words he warns his opponent to whom he has labeled as corrupt mafia. He used negative politeness strategy of 'impersonalize speaker and hearer'.

\section{Datum 23. Either the ... corrupt people. (sc.124)}

The speaker, while addressing the corrupt persons, once again reiterates his resolution that he is not going the individuals who are involved in corrupt practices. He does not mention the name of anyone. He used positive politeness strategy of notice and attend hearer. 
Datum 24. The government ... on priority. (sc.125)

The addressee's of the addresser in this datum is specifically the widows and petitioners at lower and higher courts who have been complaining about delayed justice. He says that he would ameliorate the situation with the active cooperation of chief justice of the apex court. He used negative politeness strategy 'go on record as incurring debt or not as indebting the hearer in the utterance.

\section{Datum 25.PTI registered ... professional lines.(sc.128)}

The addresser informs the audience that his party has emerged as majority party in Khyber Pakhtunkhwa just because of police reforms in the province. He used positive politeness strategy 'exaggerate (interest, approval and sympathy with hearer)' as the speaker notices the condition of the audience that they need institution building through reforms.

\section{Datum 26. A task force ... government-run hospitals. (sc.139)}

The speaker while addressing the nation says that his government would focus on state run hospitals and improve their condition. To redress the threat of FTA speaker uses positive politeness strategy 'offer or promise' in the utterance.

\section{Datum 27. The government ... of expatriates. (sc.147)}

The speaker is well aware of the water issue. He promises that his government would do concerted efforts in this regard. He says that his government would collect funds for the construction of new dams and it will be done with the help of Pakistanis who are living abroad. They would be requested to contribute in the dam fund. By uttering this sentence the speaker

\section{Datum 28. Political interferences ... the country. (sc.149)}

The addresser while addressing Pakistanis in general and civil servants in particular says that once our bureaucracy was considered as ideal bureaucracy but now political meddlesomeness has destroyed its image. He applied negative politeness strategy (be conventionally indirect) by being indirect. He has not directly stated who did political interference and who violated merit policy. He used two positive politeness strategies (offer or promise and intensify interest to hearer).

Datum 29. Bonuses were ... were penalized. (sc.153)

The speaker while telling the performance of his previous government in KPP says that reward or punishment was given to the government department with regard to their performance. He remained conventionally indirect in telling this. In other words he used negative politeness strategy. 
Datum 30. In the ... development funds. (sc.156)

He informs the audience that the current democratic system makes chief ministerial powerful. He further says that all funds have been given to MNAs and MPAs. He does not mention the agency who gave these powers to chief minister and funds to MNAs or MPAs. He redress the FTA by using negative politeness strategy i.e. be conventionally indirect.

\section{Datum 31. Former PM... foreign visits.(sc.208)}

The interlocutor indicates that the former Prime Minister (Nawaz Sharif) and the speaker National Assembly have spent a huge amount on foreign visits and trips. He does the FTA by using bald on strategy.

\section{Conclusion}

In order to meet the objectives of the study the researchers pragmatically analyzed the maiden speech of the newly elected Prime Minister of Pakistan. The data suggested that the speaker while doing face threatening acts used bald off and bald on strategies. While using bald on strategies he used both negative and positive politeness strategies with redressive action. The newly elected Prime Minister used positive politeness strategies more than negative politeness strategies because of a number of reasons. Firstly, it was his first formal address to the nation after becoming Prime Minister. So he needed to be formal and all-encompassing. Secondly, his previous speeches had been considered as highly face threatening ones. He wanted to change the old impression by remaining friendly and open towards audience. Thirdly, he was well-aware of the fact that he had become Prime Minister of a country and his words carried meaning for international community. So he was careful in the choice of strategies or words. However, he used negative politeness strategies too. Imran Khan has delivered a number of speeches on different occasions and platforms. Owing to the restricted resources the present study uses only his first formal speech, addressed to the nation as newly elected Prime Minister of Pakistan, as data. Further research can be conducted on all of Imran Khan's formal political speeches to have a comprehensive view regarding politeness strategies. The formal political speeches of other Pakistani political leaders, with Urdu as their L1, can also be analyzed in terms of politeness. Such study would be critical as it provided an insight into the pragmatic concepts of politeness and politeness strategies used by Pakistani (Urdu) speakers. 


\section{References}

Alavidze, M. (2018). Politeness in president Donald Trump's speeches. International Journal of Multidisciplinary Thought. 7(3), 119-126.

Anwar, M. N.Razaullah.Ahmed, N.\& Ali, M. (2015).Critical discourse analysis of Quaid-e-Azam Muhammad Ali Jinnah's (11th August,1947) speech in the first Constituent Assembly of Pakistan. A Research Journal of South Asian Studies. 30(1),159-173.

Brown, G. (1996). Speakers, Listeners and Communication. Cambridge: Cambridge University Press.

Brown, G. \& Yule, G. (1986). Discourse analysis. Cambridge: Cambridge University Press.

Brown, P. \& Levinson, S. (1978). Politeness. Cambridge: Cambridge University Press.

Brown, P. \& Levinson, S. (1987). Politeness: Some Universals in Language Use. Cambridge: Cambridge University Press.

Foley, W. (1997). Anthropological Linguistics: an introduction. Oxford: Basil.

Blackwell. F. S. (2003). Request and culture: politeness in British English and Japanese. Bern Peter Lang.

Goffman, E. (1969). Strategic Interaction. Philadelphia: University of Pennsylvania Press.

Grice, P. (1975). Logic and conversation in Cole, P. \&Morgan, J. (Eds.) Syntax and Semantics (pp 41-58). New York: Academic Press.

Handoko, P. Z. (2014). Politeness Strategies in Tony Abbott's Speech Concerning Australia-Indonesia Tapping Issue. Universitas Brawijaya.Dissertation

Holmes, J. (1992). An introduction of sociolinguistics. London: Longman.

Kasuma, A. (2014). Politeness Strategies in Barrack Obama's Speech in Democratic National Convention 2012. PhD dissertation, Syarif Hidyatullah State Islamic University Jakarta.

Khalil, U. Islam, M. Chattha, S, A. \& Qabalah, F. (2017). Persuasion and political discourse: a critical discourse analysis of Imran Khan's election speech (2013). Pakistan Vision, Vol. 18,193-210.

Khan, Z. M. \& Anwar, M, N. (2016). Analysis of Positive and Negative Politeness Strategies in Trump's Interview to New York Times. Science International.(Lahore). 28 (4). 703-708 
Lakoff, R, T. (1979). Stylistic strategies within a grammar of style. Annals of New York Academy of Sciences. 327(1), 53-78.

Lakoff, R, T. (1972). Language in context. Language, 48, 907-927.

Leech, G. (1983). Principles of Pragmatics. New York: Longman.

Renea, J. (1993). Discourse study: an introductory textbook. Philadelphia: John Benjamin Publishing Company.

Sari. Y, K. (2016). An Analysis of Politeness Strategies in Barrack Obama's Victory Speech. PhD dissertation, Syarif Hidayatullah State Islamic University, Jakarta.

Sibtain, M.Aslam, M. Zammad, A.\& Khan, M. (2020).Rhetorical and Persuasive Strategies Employed by Imran Khan in his Victory Speech: A Socio-Political Discourse Analysis. International Journal of English Linguistics, Vol.10, No. 2, 349356

Strauss, A. \& Corbin, J. (1990a). Basics of qualitative research: Techniques and procedures for developing grounded theory. Newbury Park, CA: Sage

Wardaugh, R. (1987). Languages in competition, Oxford: Blackwell.

Wardaugh, R. (2006). An introduction to sociolinguistics. United Kingdom. Basil Blackwell. Watts, R. (2003). Politeness. Cambridge, Cambridge University Press.

Yasmeen, R. Jabeen, M. \& Aatika, A. (2014). Politeness and the Language of Pakistani Politicians. Academic Research International. Vol. 5(3), 245-253 
